\title{
Karakteristik dan Aktivitas Penyuluh Perikanan Swadaya (PPS) di Kabupaten Bogor
}

[The Characteristics And Activities Of Voluntary Fisheries Extension Agents (PPS) In Bogor Regency]

Tuti Susilawati ${ }^{\bowtie}$

Sekolah Tinggi Perikanan, Jurusan Penyuluhan Perikanan Jalan Cikaret Nomor 1 Bogor 16001, Jawa Barat

Diterima: 16 Juli 2015; Disetujui: 7 Desember 2015

\begin{abstract}
Abstrak
Kajian Identifikasi karakteristik dan Aktivitas penyuluh perikanan swadaya (PPS) di Kabupaten Bogor, dilaksanakan pada bulan Januari-Maret 2014. Penelitian ini bertujuan untuk menganalisis karakteristik dan aktivitas PPS di Kabupaten Bogor, dan menganalisis hubungan keduanya. Metode penelitian yang digunakan survei dan wawancara, yang merupakan sensus terhadap 31 orang responden PPS. Hasil analisis uji Pearson Chi Square dengan taraf kepercayaan $\sigma=0.05$ menunjukkan bahwa karakteristik internal/ pribadi dan karakteristik eksternal PPS secara parsial berhubungan nyata dengan aktivitas PPS.
\end{abstract}

\begin{abstract}
The analysis on Voluntary Fisheries Extension Agents (Penyuluh Perikanan Swadaya-PPS) in Bogor Regency was conducted on January-March 2014. The main objectives of the study are to identify PPS characteristics and activities, and also to identify the relationship of those two factors. Survey was chosen as the method of the study, to identify 31 PPS as respondent of the study. The results of Pearson Chi-Square analysis with $\sigma=0.05$ indicated that both internal and external characteristics of PPS were significantly related to PPS activites.
\end{abstract}

\section{PENDAHULUAN}

Undang-Undang Nomor 16

Tahun 2006 tentang Sistem Penyuluhan

Pertanian, Perikanan, dan Kehutanan dalam pasal 20 ayat 1 mengamanatkan bahwa "Kegiatan penyuluhan dilakukan

\footnotetext{
$\triangle$ Penulis korespondensi

Alamat surel:astuti_syifa@yahoo.co.id
}

oleh penyuluh PNS, penyuluh swasta dan penyuluh swadaya". Keberadaan penyuluh swasta dan penyuluh swadaya bersifat mandiri untuk memenuhi kebutuhan pelaku utama dan pelaku usaha. Dengan diberlakukannya UU No.32 Tahun 2004 tentang Pemerintahan Daerah serta UU No. 16 Tahun 2006 tentang Sistem Penyuluhan Pertanian, Perikanan dan Kehutanan dan peraturan- 
Tabel 1. Jumlah Penyuluh Perikanan yang Tercatat di Pusat Penyuluhan Kelautan dan Perikanan tahun 2013.

\begin{tabular}{|c|l|r|r|}
\hline No & Jenis Penyuluh & Pusat (orang) & Persentase (\%) \\
\hline 1 & PenyuluhPNS & 3356 & 32,8 \\
\hline 2 & Penyuluh CPNS & 64 & 0,6 \\
\hline 3 & PPTK & 1428 & 14 \\
\hline 4 & PPTK Daerah & 71 & 0,7 \\
\hline 5 & Swasta & 2 & 0,01 \\
\hline 6 & Honorer & 47 & 0,4 \\
\hline 7 & Penyuluh Perikanan Swadaya & $\mathbf{5 2 7 4}$ & 51,5 \\
\hline \multicolumn{2}{|c|}{ Jumlah } & $\mathbf{1 0 2 4 2}$ & $\mathbf{1 0 0}$ \\
\hline
\end{tabular}

peraturan yang mengikutinya, konsep penyuluhan menjadi berubah. Paradigma pembangunan perikanan telah bergeser dari pendekatan sentralistik menjadi desentralistik. Penyelenggaraan penyuluhan perikanan diserahkan sepenuhnya kepada pemerintah daerah. Salah satunya yaitu termasuk kebutuhan tenaga penyuluh yang sulit dipenuhi oleh pemerintah. Dalam kondisi ini, maka keberadaan penyuluh swasta dan swadaya diperlukan untuk menyokong keberhasilan sistem penyuluhan yang dikembangkan di Indonesia.
Jumlah penyuluh perikanan yang tercatat di Pusat Penyuluh Perikanan KP pada tahun 2013 yaitu 10242 orang (tabel 1). Terlihat bahwa Penyuluh Perikanan Swadaya (PPS) cenderung lebih banyak jumlahnya dibandingkan dengan Penyuluh lainnya $(51,4 \%)$.

Sebagai ilustrasi kondisi ketenagaan penyuluh perikanan di beberapa kabupaten di Provinsi Jawa Barat dapat dilihat pada Tabel 2.

Berdasarkan Tabel 2, Kabupaten Bogor mempunyai jumlah penyuluh lebih banyak d ibandingkan dengan kabupaten lainnya, dan PPS lebih banyak

Tabel 2. Jumlah Penyuluh Perikanan di Provinsi Jawa Barat, Kabupaten Bogor, Sukabumi, Cianjur dan Bandung.

\begin{tabular}{|c|c|c|c|c|c|c|c|c|c|c|c|}
\hline \multirow{2}{*}{ No } & \multirow{2}{*}{ Penyuluh } & \multicolumn{2}{|c|}{ Jawa Barat } & \multicolumn{2}{|c|}{ Bogor } & \multicolumn{2}{|c|}{ Sukabumi } & \multicolumn{2}{|c|}{ Cianjur } & \multicolumn{2}{|c|}{ Bandung } \\
\hline & & Org & $\%$ & org & $\%$ & org & $\%$ & org & $\%$ & org & $\%$ \\
\hline 1 & Penyuluh PNS & 207 & 28,5 & 18 & 28 & 27 & 48 & 2 & 22 & 12 & 43 \\
\hline 2 & Penyuluh CPNS & 8 & 1,1 & 5 & 8 & - & - & 1 & 11 & - & - \\
\hline 3 & PPTK & 122 & 16,8 & 8 & 12 & 10 & 18 & 6 & 67 & 3 & 11 \\
\hline 4 & PPTK Daerah & 4 & 0,5 & - & - & - & - & - & - & - & - \\
\hline 5 & Swasta & 1 & 0,1 & - & - & - & - & - & - & - & - \\
\hline 6 & Honorer & - & - & - & - & - & - & - & - & - & - \\
\hline 7 & PPS & 385 & 53 & 33 & 52 & 19 & 34 & - & - & 13 & 46 \\
\hline & Jumlah & 727 & 100 & 64 & 100 & 56 & 100 & 9 & 100 & 28 & 100 \\
\hline
\end{tabular}

Sumber : Pusluh KP, 2013 
Kabupaten Bogor mempunyai jumlah 40 kecamatan dengan jumlah Pokdakan sekitar 250 kelompok atau 8176 RTP. Setiap penyuluh perikanan PNS telah memiliki wilayah binaan 2-3 kecamatan sementara dalam 1 kecamatan terdapat 610 desa. Dengan kondisi ini, penyelenggaraan penyuluhan belum optimal jika melihat luas wilayah dan banyaknya Pokdakan yang memiliki tingkat kemampuan dan pengetahuan yang beragam. Agar penyelenggaraan penyuluhan perikanan dapat terlaksana sesuai dengan potensi dan ragam permasalahan yang dihadapi wilayah masing-masing, diperlukan koordinasi dan fasilitasi pemerintah pusat, provinsi, dan kabupaten/kota (BKP5K, 2013).

Salah satu upaya yang dilakukan adalah dengan mengaktifkan PPS yaitu melalui pengukuhan PPS dengan Keputusan Kepala Badan Ketahanan Pangan dan Pelaksana Penyuluhan Pertanian, Perikanan, dan Kehutanan (BKP5K) Kab. Bogor No. 520/22.a/Kpts/BKP5K/2013 tentang Penetapan Daftar Nominatif Penyuluh Swadaya Kegiatan Penyediaan Jasa Non PNS pada Badan Ketahanan Pangan dan Pelaksana Penyuluhan, Perikanan dan Kehutanan Kab. Bogor Tahun 2013. PPS adalah pelaku utama yang berhasil dalam usahanya dan warga masyarakat lainnya yang dengan kesadarannya sendiri mau dan mampu menjadi penyuluh (UU No. 16 tahun 2006 Pasal 1 ayat 20). Namun tidak sesederhana pemikiran bahwa dengan pengukuhan PPS saja sudah cukup sebagai bukti ketenagaan penyuluh bertambah. Belum lagi melihat luas wilayah binaan yang tidak ada penyuluh perikanan di kecamatan bersangkutan sehingga PPS yang ditempatkan harus memiliki konsekuensi kemandirian khusus untuk menyelenggarakan kegiatan penyuluhan. Jumlah PPS di Kabupaten Bogor sekitar 31 orang. Untuk itu perlu dilihat kinerja PPS dalam mengimplementasikan kebijakan tersebut, yang sekaligus daat menunjukkan bagaimana PPS dapat melaksanakan aktivitasnya dengan baik.

\section{Tujuan}

1. Menganalisis karakteristik penyuluh perikanan swadaya.

2. Menganalisis aktivitas penyuluh Perikanan Swadaya

3. Menganalisis hubungan karakteristik PPS dengan aktivitas-aktivitasnya

\section{Kerangka Pemikiran}




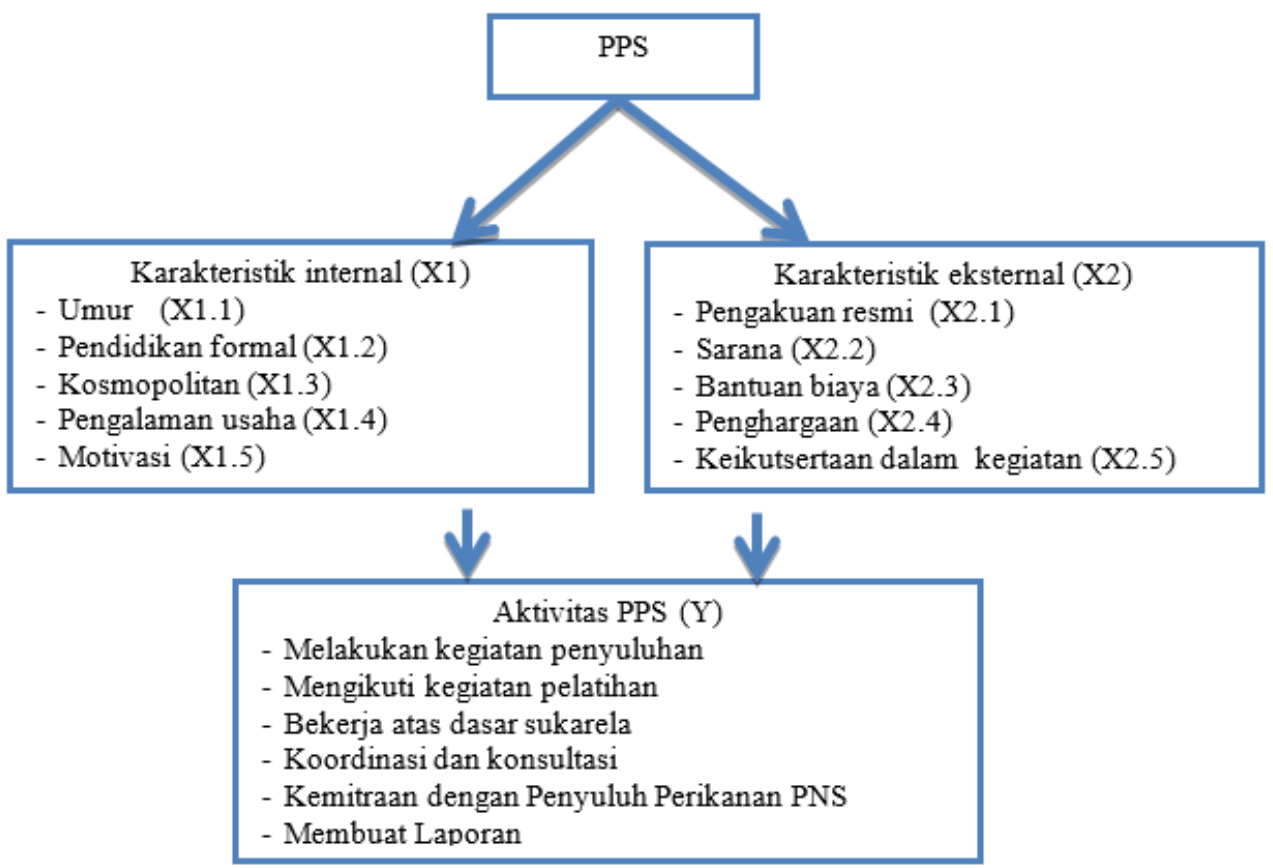

Gambar 1. Kerangka Pemikiran Penelitian

Karakteristik PPS dibedakan atas

Karakteristik Internal dan Karakteristik

Eksternal. Karakteristik Internl PPS

meliputi: Umur, Pendidikan formal,

Kosmopolitan, Pengalaman usaha,

\section{METODE PENELITIAN}

Motivasi. Karakteristik Eksternal PPS meliputi: Pengakuan resmi, Sarana, Bantuan biaya, Penghargaan, Keikutsertaan dalam kegiatan.

Sementara itu, aktivitas yang dilakukan oleh PPS mencakup kegiatan-kegiatan: Melakukan kegiatan penyuluhan, Mengikuti kegiatan pelatihan, Bekerja atas dasar sukarela, Koordinasi dan konsultasi, Kemitraan dengan Penyuluh Perikanan PNS, Membuat Laporan.

Secara garis besar kerangka pemikiran dalam penelitian ini dapat dilihat pada Gambar 1.

Penelitian dilakukan pada bulan Januari-Maret Tahun 2014 di Kabupaten Bogor, Jawa Barat. Penentuan lokasi dilakukan secara sengaja (purposive) dengan pertimbangan bahwa : 1). Kabupaten Bogor merupakan salah satu kawasan minapolitan, yang menjadi salah satu wilayah dalam pengukuhan PPS oleh Pusat Pengembangan Penyuluhan KKP; 2). Jumlah PPS di BKP5K lebih banyak dibandingkan dengan penyuluh lainnya, Dibandingkan dengan kabupaten lain (wilayah Provinsi Jawa Barat); 3). Kabupaten Bogor telah memberikan perhatian terhadap PPS. 
Karakteristik internal/pribadi PPS yang dihubungkan dengan kewajiban

Tabel 3. Hubungan Umur PPS dengan Kewajiban PPS

\begin{tabular}{|l|l|c|c|c|}
\hline \multirow{2}{*}{ No } & \multirow{2}{*}{ Kewajiban PPS } & \multicolumn{3}{|c|}{ Karakteristik Internal PPS } \\
\cline { 3 - 5 } & & \multicolumn{3}{c|}{ Umur } \\
\cline { 3 - 5 } & & P-Value & Probabilitas & Keterangan \\
\hline 1 & $\begin{array}{l}\text { Melakukan kegiatan } \\
\text { penyuluhan }\end{array}$ & 1.849 & 0.763 & Tidak Signifikan \\
\hline 2 & Mengikuti Pelatihan & 2.179 & 0.703 & Tidak Signifikan \\
\hline 3 & Bekerja atas dasar sukarela & 4.896 & 0.298 & Tidak Signifikan \\
\hline 4 & $\begin{array}{l}\text { Melakukan koordinasi dan } \\
\text { konsultasi }\end{array}$ & 4.084 & 0.665 & Tidak Signifikan \\
\hline 5 & Kemitraan & $14.430^{\circ}$ & $0.025^{*}$ & Signifikan \\
\hline 6 & Membuat Laporan & 2.094 & 0.718 & Tidak Signifikan \\
\hline
\end{tabular}

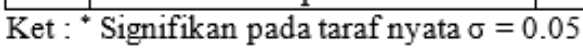

\section{Populasi dan Sampel}

Pihak yang menjadi responden utama dalam penelitian ini adalah PPS, sedang responden tambahan adalah Pusluh KP, BKP5K Kabupaten Bogor, Dinas Peternakan dan Perikanan Kabupaten Bogor, dan Penyuluh PNS sebagai mitra dari PPS serta pembudidaya ikan yang menjadi binaannya.

\section{Analisis Data}

Analisis data dilakukan dengan analisis data kuantitatif dan kualitatif (mixed methods). Data kuantitatif dan data kualitatif akan dikombinasikan secara berurutan (sequential).

\section{HASIL DAN PEMBAHASAN}

\section{Hubungan Karakteristik Internal (X1)}

dengan Kewajiban PPS (Y)
PPS/aktifitas PPS adalah : umur, pendidikan formal, akses ke sumber media dan informasi, pengalaman, dan motivasi menjadi PPS. Selengkapnya dari analisis Perason Chi Square disajikan hubungan-hubungan sebagai berikut :

Hubungan Umur PPS dengan Kewajiban PPS

Hasil penelitian tentang hubungan umur PPS dengan kewajiban PPS dapat dilihat pada Tabel 3.

Dari hasil analisis terbukti bahwa umur PPS berpengaruh signifikan terhadap kemitraan dengan Penyuluh Perikanan PNS dengan P-Value sebesar 14.430 dan nilai probabilitas sebesar 0.025 pada taraf kepercayaan $\sigma 0.05$.

Hubungan Pendidikan Formal dengan Kewajiban PPS 
Hasil penelitian tentang hubungan pendidikan formal PPS dengan kewajiban PPS dapat dilihat pada Tabel 4.
Dari hasil analisis terbukti bahwa kosmopolitan berpengaruh signifikan terhadap kewajiban PPS yaitu melakukan

Tabel 4. Hubungan Pendidikan Formal PPS dengan Kewajiban PPS

\begin{tabular}{|l|l|c|c|c|}
\hline \multirow{2}{*}{ No } & \multirow{2}{*}{ Kewajiban PPS } & \multicolumn{3}{|c|}{ Karakteristik Internal PPS } \\
\cline { 3 - 5 } & & \multicolumn{3}{|c|}{ Pendidikan Formal } \\
\cline { 3 - 5 } & $\begin{array}{l}\text { Melakukan kegiatan } \\
\text { penyuluhan }\end{array}$ & 2.960 & 0.814 & Tidak Signifikan \\
\hline 2 & Mengikuti Pelatihan & $13.245^{*}$ & $0.039^{*}$ & Signifikan \\
\hline 3 & Bekerja atas dasar sukarela & 3.434 & 0.765 & Tidak Signifikan \\
\hline 4 & $\begin{array}{l}\text { Melakukan koordinasi dan } \\
\text { konsultasi }\end{array}$ & 7.024 & 0.635 & Tidak Signifikan \\
\hline 5 & Kemitraan & 10.851 & 0.296 & Tidak Signifikan \\
\hline 6 & Membuat Laporan & 4.593 & 0.597 & Tidak Signifikan \\
\hline
\end{tabular}

Ket : ${ }^{*}$ Signifikan pada taraf nyata $\sigma=0.05$

Dari hasil analisis terbukti bahwa pendidikan formal PPS berpengaruh signifikan terhadap kewajiban PPS mengikuti pelatihan bidang penyuluhan perikanan.

\section{Hubungan Kosmopolitan dengan}

\section{Kewajiban PPS}

Hasil penelitian tentang hubungan kosmopolitan dengan kewajiban PPS dapat dilihat pada Tabel 5. kegiatan penyuluhan perikanan dan melakukan koordinasi dan konsultasi dengan Penyuluh Perikanan PNS dan kelembagaan penyuluhan perikanan di wilayahnya, serta membuat laporan.

Hubungan Pengalaman Usaha dengan Kewajiban PPS

Hasil penelitian tentang hubungan pengalaman PPS dengan kewajiban PPS dapat dilihat pada Tabel 6 .

Tabel 5. Hubungan Kosmopolitan dengan Kewajiban PPS

\begin{tabular}{|l|l|c|c|c|}
\hline \multirow{2}{*}{ No } & \multirow{2}{*}{ Kewajiban PPS } & \multicolumn{3}{|c|}{ Karakteristik Internal PPS } \\
\cline { 3 - 5 } & & \multicolumn{2}{|c|}{ Akses ke Sumber Media dan Informasi } \\
\cline { 3 - 5 } & & P-Value & Probabilitas & Keterangan \\
\hline 1 & $\begin{array}{l}\text { Melakukan kegiatan } \\
\text { penyuluhan }\end{array}$ & $14.247^{*}$ & $0.007^{*}$ & Signifikan \\
\hline 2 & Mengikuti Pelatihan & 4.715 & 0.318 & Tidak Signifikan \\
\hline 3 & Bekerja atas dasar sukarela & 1.997 & 0.736 & Tidak Signifikan \\
\hline 4 & $\begin{array}{l}\text { Melakukan koordinasi dan } \\
\text { konsultasi }\end{array}$ & $16.051^{*}$ & $0.013^{*}$ & Signifikan \\
\hline 5 & Kemitraan & 8.268 & 0.219 & Tidak Signifikan \\
\hline 6 & Membuat Laporan & $10.758^{*}$ & $0.029^{*}$ & Signifikan \\
\hline
\end{tabular}


Tabel 6. Hubungan Pengalaman Usaha dengan Kewajiban PPS

\begin{tabular}{|l|l|c|c|c|}
\hline \multirow{2}{*}{ No } & \multirow{2}{*}{ Kewajiban PPS } & \multicolumn{3}{|c|}{ Karakteristik Internal PPS } \\
\cline { 3 - 5 } & & \multicolumn{3}{|c|}{ Pengalaman } \\
\cline { 3 - 5 } & & P-Value & Probabilitas & Keterangan \\
\hline 1 & $\begin{array}{l}\text { Melakukan kegiatan } \\
\text { penyuluhan }\end{array}$ & $11.739^{*}$ & $0.019^{*}$ & Signifikan \\
\hline 2 & Mengikuti Pelatihan & 3.257 & 0.516 & Tidak Signifikan \\
\hline 3 & Bekerja atas dasar sukarela & $9.544^{*}$ & $0.049^{*}$ & Signifikan \\
\hline 4 & $\begin{array}{l}\text { Melakukan koordinasi dan } \\
\text { konsultasi }\end{array}$ & 9.472 & 0.149 & Tidak Signifikan \\
\hline 5 & Kemitraan & $12.808^{*}$ & $0.046^{*}$ & Signifikan \\
\hline 6 & Membuat Laporan & $10.504^{*}$ & $0.033^{*}$ & Signifikan \\
\hline
\end{tabular}

Hasil penelitian menunjukkan

bahwa terdapat hubungan yang signifikan antara pengalaman usaha dengan kewajiban PPS melakukan kegiatan penyuluhan perikanan, Bekerja Atas Dasar Sukarela, Kemitraan, dan Membuat Laporan.

\section{Hubungan Motivasi dengan Kewajiban} $P P S$

Hasil penelitian tentang hubungan motivasi PPS dengan kewajiban PPS dapat dilihat pada Tabel 7.

Dari hasil uji Pearson Chi Square ternyata motivasi menjadi PPS berpengaruh signifikan terhadap kewajiban PPS melakukan kegiatan penyuluhan perikanan.

Hubungan Karakteristik Eksternal (X2) dengan Kewajiban PPS $(Y)$

Karakteristik ekternal/hal PPS yang dihubungkan dengan kewajiban PPS/aktifitas PPS adalah : pengakuan, sarana dan prasarana, bantuan biaya, penghargaan, dan keikutsertaan dalam kegiatan. Selengkapnya dari analisis Perason Chi Square disajikan hubunganhubungan sebagai berikut :

Tabel 7. Hubungan Motivasi PPS dengan Kewajiban PPS

\begin{tabular}{|l|l|c|c|c|}
\hline \multirow{2}{*}{ No } & \multirow{2}{*}{ Kewajiban PPS } & \multicolumn{3}{|c|}{ Karakteristik Internal PPS } \\
\cline { 3 - 5 } & & \multicolumn{3}{|c|}{ Motivasi } \\
\cline { 3 - 5 } & $\begin{array}{l}\text { Melakukan kegiatan } \\
\text { penyuluhan }\end{array}$ & $9.439^{*}$ & $0.009^{*}$ & Signifikan \\
\hline 2 & Mengikuti Pelatihan & $6.359^{*}$ & $0.042^{*}$ & Signifikan \\
\hline 3 & Bekerja atas dasar sukarela & $7.642^{*}$ & $0.022^{*}$ & Signifikan \\
\hline 4 & $\begin{array}{l}\text { Melakukan koordinasi dan } \\
\text { konsultasi }\end{array}$ & 2.909 & 0.406 & Tidak Signifikan \\
\hline 5 & Kemitraan & 1.004 & 0.800 & Tidak Signifikan \\
\hline 6 & Membuat Laporan & 0.199 & 0.905 & Tidak Signifikan \\
\hline
\end{tabular}

Ket : ${ }^{*}$ Signifikan pada taraf nyata $\sigma=0.05$ 
Tabel 8. Hubungan Pengakuan dengan Kewajiban PPS

\begin{tabular}{|l|l|c|c|c|}
\hline \multirow{2}{*}{ No } & \multirow{2}{*}{ Kewajiban PPS } & \multicolumn{3}{|c|}{ Karakteristik Eksternal PPS } \\
\cline { 3 - 5 } & & \multicolumn{3}{|c|}{ Motivasi } \\
\cline { 3 - 5 } & & P-Value & Probabilitas & Keterangan \\
\hline 1 & $\begin{array}{l}\text { Melakukan kegiatan } \\
\text { penyuluhan }\end{array}$ & $7.272^{*}$ & $0.026^{*}$ & Signifikan \\
\hline 2 & Mengikuti Pelatihan & 1.735 & 0.420 & Tidak Signifikan \\
\hline 3 & Bekerja atas dasar sukarela & 5.294 & 0.071 & Tidak Signifikan \\
\hline 4 & $\begin{array}{l}\text { Melakukan koordinasi dan } \\
\text { konsultasi }\end{array}$ & $13.204^{*}$ & $0.004^{*}$ & Signifikan \\
\hline 5 & Kemitraan & 7.600 & 0.055 & Tidak Signifikan \\
\hline 6 & Membuat Laporan & 2.823 & 0.244 & Tidak Signifikan \\
\hline
\end{tabular}

Hubungan Pengakuan dengan Kewajiban PPS

Hasil penelitian tentang hubungan pengakuan dengan kewajiban PPS dapat dilihat pada Tabel 8 .

Dari hasil uji Pearson Chi Square ternyata pengakuan resmi dari pemerintah berpengaruh signifikan terhadap kewajiban PPS melakukan kegiatan penyuluhan perikanan dan melakukan koordinasi dan konsultasi dengan Penyuluh Perikanan PNS dan kelembagaan penyuluhan perikanan di wilayahnya.

\section{Hubungan Sarana dan Prasarana}

dengan Kewajiban PPS

Hasil penelitian tentang hubungan sarana dan prasarana dengan kewajiban PPS dapat dilihat pada Table 9.

Tabel 9. Hubungan Sarana dan Prasarana dengan Kewajiban PPS

\begin{tabular}{|l|l|c|c|c|}
\hline \multirow{2}{*}{ No } & \multirow{2}{*}{ Kewajiban PPS } & \multicolumn{3}{|c|}{ Karakteristik Eksternal PPS } \\
\cline { 3 - 5 } & & \multicolumn{3}{|c|}{ Motivasi } \\
\cline { 3 - 5 } & & P-Value & Probabilitas & Keterangan \\
\hline 1 & $\begin{array}{l}\text { Melakukan kegiatan } \\
\text { penyuluhan }\end{array}$ & 7.082 & 0.132 & Tidak Signifikan \\
\hline 2 & Mengikuti Pelatihan & 3.156 & 0.532 & Tidak Signifikan \\
\hline 3 & Bekerja atas dasar sukarela & $11.936^{*}$ & $0.018^{*}$ & Signifikan \\
\hline 4 & $\begin{array}{l}\text { Melakukan koordinasi dan } \\
\text { konsultasi }\end{array}$ & 3.311 & 0.769 & Tidak Signifikan \\
\hline 5 & Kemitraan & 2.948 & 0.815 & Tidak Signifikan \\
\hline 6 & Membuat Laporan & 2.118 & 0.714 & Tidak Signifikan \\
\hline
\end{tabular}


Tabel 10. Hubungan Bantuan Biaya dengan Kewajiban PPS

\begin{tabular}{|l|l|c|c|c|}
\hline \multirow{2}{*}{ No } & \multirow{2}{*}{ Kewajiban PPS } & \multicolumn{3}{c|}{ Karakteristik Eksternal PPS } \\
\cline { 3 - 5 } & & \multicolumn{3}{c|}{ Motivasi } \\
\cline { 3 - 5 } & $\begin{array}{l}\text { Melakukan kegiatan } \\
\text { penyuluhan }\end{array}$ & 2.583 & 0.859 & Tidak Signifikan \\
\hline 2 & Mengikuti Pelatihan & 3.947 & 0.684 & Tidak Signifikan \\
\hline 3 & Bekerja atas dasar sukarela & 4.150 & 0.656 & Tidak Signifikan \\
\hline 4 & $\begin{array}{l}\text { Melakukan koordinasi dan } \\
\text { konsultasi }\end{array}$ & $22.609^{*}$ & $0.007^{*}$ & Signifikan \\
\hline 5 & Kemitraan & $22.281^{*}$ & $0.008^{*}$ & Signifikan \\
\hline 6 & Membuat Laporan & $12.630^{*}$ & $0.049^{*}$ & Signifikan \\
\hline
\end{tabular}

Ket : ${ }^{*}$ Signifikan pada taraf nyata $\sigma=0.05$

Dari hasil uji Pearson Chi Square ternyata sarana dan prasarana berpengaruh signifikan terhadap kewajiban PPS bekerja atas dasar sukarela dan tidak menerima gaji/honorarium sebagaimana Penyuluh Perikanan PNS.

\section{Hubungan Bantuan Biaya dengan}

Kewajiban PPS

Hasil penelitian tentang hubungan bantuan biaya dengan kewajiban PPS dapat dilihat pada Tabel 10 .

Dari hasil uji Pearson Chi Square ternyata bantuan biaya berpengaruh signifikan terhadap kewajiban PPS melakukan koordinasi dan konsultasi dengan Penyuluh Perikanan PNS dan kelembagaan penyuluhan perikanan diwilayahnya, dan kemitraan dengan Penyuluh Perikanan PNS.

\section{Hubungan Penghargaan dengan}

\section{Kewajiban PPS}

Hasil penelitian tentang hubungan penghargaan dengan kewajiban PPS dapat dilihat pada Tabel 11.

Dari hasil uji Pearson Chi Square ternyata penghargaan berpengaruh signifikan terhadap kewajiban PPS melakukan koordinasi dan konsultasi dengan Penyuluh Perikanan PNS dan

Tabel 11. Hubungan Penghargaan dengan Kewajiban PPS

\begin{tabular}{|l|l|c|c|c|}
\hline \multirow{2}{*}{ No } & \multirow{2}{*}{ Kewajiban PPS } & \multicolumn{3}{|c|}{ Karakteristik Eksternal PPS } \\
\cline { 3 - 5 } & & \multicolumn{3}{|c|}{ Motivasi } \\
\cline { 3 - 5 } & & P-Value & Probabilitas & Keterangan \\
\hline 1 & $\begin{array}{l}\text { Melakukan kegiatan } \\
\text { penyuluhan }\end{array}$ & 8.737 & 0.068 & Tidak Signifikan \\
\hline 2 & Mengikuti Pelatihan & 6.885 & 0.142 & Tidak Signifikan \\
\hline 3 & Bekerja atas dasar sukarela & 2.384 & 0.666 & Tidak Signifikan \\
\hline 4 & $\begin{array}{l}\text { Melakukan koordinasi dan } \\
\text { konsultasi }\end{array}$ & $16.864^{*}$ & $0.010^{*}$ & Signifikan \\
\hline 5 & Kemitraan & 10.846 & 0.093 & Tidak Signifikan \\
\hline 6 & Membuat Laporan & $11.440^{*}$ & $0.022^{*}$ & Signifikan \\
\hline
\end{tabular}


kelembagaan penyuluhan perikanan diwilayahnya.

\section{Hubungan Keikutsertaan dalam Kegiatan} dengan Kewajiban PPS

Hasil penelitian tentang hubungan keikutsertaan dalam kegiatan dengan kewajiban PPS dapat dilihat pada Tabel 12.

Dari hasil uji Pearson Chi Square keikutsertaan dalam kegiatan yang difasilitasi oleh pemerintah berpengaruh signifikan terhadap kewajiban PPS yaitu melakukan koordinasi dan konsultasi dengan Penyuluh Perikanan PNS dan kelembagaan penyuluhan perikanan diwilayahnya dan kemitraan dengan Penyuluh Perikanan PNS serta membuat laporan.

\section{Pembahasan Hasil Analisis}

\section{Hubungan Karakteristik Internal/Pribadi}

PPS dengan Kewajiban PPS

Berdasarkan hasil analisis Pearson Chi Square pada taraf dalam penelitian ini maka didapatkan hubungan yang signifikan maupun tidak signifikan antara karakteristik pribadi PPS dengan enam kewajiban PPS.

Hubungan antara umur PPS dengan keenam kewajiban dari hasil analisis ini menunjukkan bahwa umur PPS berkorelasi positif atau berhubungan signifikan dengan kewajiban PPS yaitu kemitraan dengan penyuluh PNS. Dengan demikian hasil dari penelitian tentang hubungan ini menyatakan bahwa umur PPS berpengaruh langsung terhadap kemitraan dengan Penyuluh Perikanan dalam hal melaksanakan kegiatan penyuluhan perikanan di Kabupaten Bogor. Menurut Van den Ban dan Hawkins (1999) penyuluhan menghendaki kemampuan yang tinggi dari agen penyuluhan dengan sikap positif terhadap pelaku utama, terutama hubungan pribadi dalam diskusi bersama. Sumardjo (2010) berpendapat bahwa kompetensi kerjasama merupakan salah

Tabel 12. Hubungan Keikutsertaan dalam Kegiatan dengan Kewajiban PPS

\begin{tabular}{|l|l|c|c|c|}
\hline \multirow{2}{*}{ No } & \multirow{2}{*}{ Kewajiban PPS } & \multicolumn{3}{|c|}{ Karakteristik Eksternal PPS } \\
\cline { 3 - 5 } & & \multicolumn{3}{|c|}{ Motivasi } \\
\cline { 3 - 5 } & & P-Value & Probabilitas & Keterangan \\
\hline 1 & $\begin{array}{l}\text { Melakukan kegiatan } \\
\text { penyuluhan }\end{array}$ & 5.801 & 0.214 & Tidak Signifikan \\
\hline 2 & Mengikuti Pelatihan & 4.351 & 0.361 & Tidak Signifikan \\
\hline 3 & Bekerja atas dasar sukarela & 4.915 & 0.296 & Tidak Signifikan \\
\hline 4 & $\begin{array}{l}\text { Melakukan koordinasi dan } \\
\text { konsultasi }\end{array}$ & $13.206^{*}$ & $0.040^{*}$ & Signifikan \\
\hline 5 & Kemitraan & $14.294^{*}$ & $0.027^{*}$ & Signifikan \\
\hline 6 & Membuat Laporan & $10.031^{*}$ & $0.040^{*}$ & Signifikan \\
\hline
\end{tabular}


penyuluh yang mandiri dicirikan oleh kemampuan internal untuk bekerjasama atau berinteraksi dengan pihak lain secara interdependent, sinergis dan berkelanjutan dalam koridor nilai- nilai sosial yang dijunjung bersama secara bermartabat. Penelitian ini sama dengan temuan Sapar (2011).

$$
\text { Hubungan antara tingkat }
$$
pendidikan PPS dengan kewajiban PPS dari hasil analisis ini menunjukkan bahwa pendidikan PPS responden berkorelasi positif atau berhubungan signifikan dengan kewajiban PPS yaitu mengikuti pelatihan bidang penyuluhan perikanan. Dengan demikian hasil dari penelitian tentang hubungan ini menyatakan bahwa tingkat pendidikan PPS berpengaruh langsung terhadap pelatihan bidang penyuluhan perikanan. Mulyasa (2003) mengemukakan bahwa pendidikan berperan dalam mewujudkan masyarakat yang berkualitas, menampilkan individu yang memiliki keunggulan yang tangguh, kreatif, mandiri, dan profesional dalam bidangnya masing-masing. Salah satu bentuk pendidikan nonformal yang sering dilakukan oleh penyuluh adalah pelatihan. Menurut Siagian (1997) salah satu cara untuk mengubah potensi seseorang menjadi kemampuan nyata ialah melalui pendidikan dan pelatihan.
Sasaran yang ingin dicapai dalam suatu pelatihan adalah mengajarkan pengetahuan dan keterampilan tertentu yang pada umumnya berupa keterampilan baru yang belum dimiliki peserta, sehingga terjadi perubahan sikap dan perilaku. Sedangkan Menurut Suryantini (2001), pendidikan baik formal maupun nonformal pada hakikatnya berfungsi sebagai sarana pemberdayaan individu untuk meningkatkan pengetahuan dan dan keterampilan dalam rangka pengembangan potensi diri. Pada umumnya seseorang yang berpendidikan lebih baik dan berpengetahuan teknis yang lebih banyak akan lebih mudah dan mampu berkomunikasi dengan baik. Selain itu kemampuan untuk menerima, menyaring, dan menerapkan hal-hal baru akan semakin baik. Sehingga makin tinggi pendidikan seseorang, maka dia akan lebih banyak melakukan komunikasi dua arah secara intensif dengan berbagai sumber informasi.

Hubungan antara kosmopolitan dengan kewajiban PPS dari hasil analisis ini menunjukkan bahwa kosmopolitan berkorelasi positif atau berhubungan signifikan dengan kewajiban PPS yaitu melakukan kegiatan penyuluhan perikanan, melakukan koordinasi dan konsultasi dengan Penyuluh Perikanan PNS dan kelembagaan penyuluhan 
perikanan diwilayahnya, dan membuat laporan. Dengan demikian hasil dari penelitian tentang hubungan ini menyatakan bahwa kosmopolitan berpengaruh langsung terhadap kewajiban PPS yakni melakukan kegiatan penyuluhan perikanan, melakukan koordinasi dan konsultasi dengan Penyuluh Perikanan PNS dan kelembagaan penyuluhan perikanan diwilayahnya dan membuat laporan kegiatan bulanan. Rogers (1969) mengemukakan bahwa seseorang dengan sifat kosmopolit yang tinggi biasanya akan mencari informasi dari sumber di luar lingkungannya, sedangkan yang rendah sifat kosmopolitnya cenderung mempunyai ketergantungan yang tinggi pada sumber informasi yang ada di lingkungannya.

Hubungan antara pengalaman usaha dengan kewajiban PPS dari hasil analisis ini menunjukkan bahwa pengalaman usaha PPS berkorelasi positif atau berhubungan signifikan dengan kewajiban PPS yaitu melakukan kegiatan penyuluhan perikanan, berkorelasi positif atau berhubungan signifikan dengan kewajiban PPS yaitu bekerja atas dasar sukarela dan tidak menerima gaji/honorarium sebagaimana Penyuluh Perikanan PNS, berkorelasi positif atau berhubungan signifikan dengan kewajiban PPS yaitu kemitraan dengan
Penyuluh Perikanan PNS, dan juga berkorelasi positif atau berhubungan signifikan pada dengan kewajiban PPS yaitu membuat laporan. Dengan demikian hasil dari penelitian tentang hubungan ini menyatakan bahwa pengalaman usaha berpengaruh langsung terhadap kewajiban PPS yakni melakukan kegiatan penyuluhan perikanan, bekerja atas dasar sukarela dan tidak menerima gaji/honorarium sebagaimana Penyuluh Perikanan PNS, kemitraan dengan Penyuluh Perikanan PNS, dan membuat laporan kegiatan bulanan.

Kondisi tersebut sejalan dengan pendapat Mardikanto (2009), bahwa semakin lama seseorang bekerja semakin baik pula pengalamannya sehingga akan memberikan kontribusi terhadap minat dan harapannya untuk belajar lebih banyak, termasuk dalam menunjang profesinya sebagai PPS. Asayehegn et al. (2012) menyatakan pengalaman kerja memiliki peran penting dalam memahami permasalahan yang dihadapi pelaku utama dan berpengaruh dalam pengembangan profesinya sebagai seorang penyuluh.

Hubungan antara motivasi menjadi PPS dengan kewajiban PPS dari hasil analisis ini menunjukkan bahwa motivasi menjadi PPS berkorelasi positif atau berhubungan signifikan dengan 
kewajiban PPS yaitu melakukan kegiatan penyuluhan perikanan, berkorelasi positif atau berhubungan signifikan dengan kewajiban PPS yaitu mengikuti pelatihan bidang penyuluhan perikanan, dan juga berkorelasi positif atau berhubungan signifikan dengan kewajiban PPS yaitu bekerja atas dasar sukarela dan tidak menerima gaji/honorarium sebagaimana Penyuluh Perikanan PNS. Dengan demikian hasil dari penelitian tentang hubungan ini menyatakan bahwa motivasi menjadi PPS berpengaruh langsung terhadap kewajiban PPS yakni melakukan kegiatan penyuluhan perikanan, mengikuti pelatihan bidang penyuluhan perikanan, dan bekerja atas dasar sukarela dan tidak menerima gaji/honorarium sebagaimana Penyuluh Perikanan PNS.

Motivasi yang dimiliki berasal dari dalam diri PPS untuk menjadi seorang penyuluh swadaya disebabkan beberapa alasan diantaranya menjadi seorang PPS adalah sebuah pekerjaan yang mulia, karena dapat berbagi ilmu dan membantu pelaku utama perikanan dilingkungannya. Keputusan untuk menjadi PPS merupakan keinginan sendiri secara sukarela untuk menyebarkan pengetahuan dan keterampilan yang dimilikinya kepada masyarakat.

\section{Hubungan Karakteristik Eksternal/Hak}

\section{PPS dengan Kewajiban PPS}

Hubungan antara pengakuan resmi dari pemerintah dengan kewajiban PPS dari hasil analisis ini menunjukkan bahwa pengakuan resmi dari pemerintah berkorelasi positif atau berhubungan signifikan dengan kewajiban PPS yaitu melakukan kegiatan penyuluhan perikanan, dan berkorelasi positif atau berhubungan signifikan dengan kewajiban PPS yaitu melakukan koordinasi dan konsultasi dengan Penyuluh Perikanan PNS dan kelembagaan penyuluhan perikanan diwilayahnya. Dengan demikian hasil dari penelitian tentang hubungan ini menyatakan bahwa pengakuan resmi dari pemerintah berpengaruh langsung terhadap kewajiban PPS yakni melakukan kegiatan penyuluhan perikanan dan melakukan koordinasi dan konsultasi dengan Penyuluh Perikanan PNS dan kelembagaan penyuluhan perikanan diwilayahnya. Hal ini diperkuat dengan Keputusan Kepala Badan Ketahanan Pangan dan Pelaksana Penyuluhan Pertanian, Perikanan, dan Kehutanan Kabupaten Bogor Nomor. 520/22.a/Kpts/BKP5K/2013 tentang penetapan daftar nominatif penyuluh pertanian swadaya kegiatan Penyediaan 
Jasa Penyuluh Non PNS pada BKP5K Kabupaten Bogor.

Hubungan antara sarana dan prasarana penyuluhan perikanan dengan kewajiban PPS dari hasil analisis ini menunjukkan bahwa sarana dan prasarana penyuluhan perikanan berkorelasi positif atau berhubungan signifikan dengan kewajiban PPS yaitu bekerja atas dasar sukarela dan tidak menerima gaji/honorarium sebagaimana Penyuluh Perikanan PNS. Dengan demikian hasil dari penelitian tentang hubungan ini menyatakan bahwa sarana dan prasarana penyuluhan perikanan berpengaruh langsung terhadap kewajiban PPS yakni bekerja atas dasar sukarela dan tidak menerima gaji/honorarium sebagaimana Penyuluh Perikanan PNS. Penyuluh perikanan swadaya dapat memanfaatkan sarana dan prasarana penyuluhan perikanan yang dimiliki oleh Pemerintah dan pemerintah daerah sesuai dengan peraturan perundang-undangan yang berlaku. Pemanfaatan sarana dan prasarana dimaksudkan agar dapat membantu dalam melaksanakan tugas pokok dan fungsinya. Hasil analisis tersebut sejalan dengan fakta di lapangan, yang menunjukkan penyuluh mengakui tersedianya sarana dan prasarana dalam mendukung kegiatan penyuluh. Hasil penelitian berbeda dengan penelitian
Hamzah (2011) yang menyimpulkan bahwa tidak ada hubungan yang nyata antara prasarana dan sarana dengan kinerja penyuluh pertanian.

Hubungan antara bantuan biaya dengan kewajiban PPS dari hasil analisis ini menunjukkan bahwa bantuan biaya berkorelasi positif atau berhubungan signifikan dengan kewajiban PPS yaitu melakukan koordinasi dan konsultasi dengan Penyuluh Perikanan PNS dan kelembagaan penyuluhan perikanan diwilayahnya, berkorelasi positif atau berhubungan signifikan dengan kewajiban PPS yaitu kemitraan dengan Penyuluh Perikanan PNS, dan juga berkorelasi positif atau berhubungan signifikan dengan kewajiban PPS yaitu membuat laporan. Dengan demikian hasil dari penelitian tentang hubungan ini menyatakan bahwa bantuan biaya PPS berpengaruh langsung terhadap kewajiban PPS yakni melakukan koordinasi dan konsultasi dengan Penyuluh Perikanan PNS dan kelembagaan penyuluhan perikanan diwilayahnya, kemitraan dengan Penyuluh Perikanan PNS dan membuat laporan kegiatan bulanan.

Bantuan biaya yang diberikan pemerintah merupakan bentuk perhatian dan dukungan terhadap PPS dalam menjalankan tugasnya sebagai seorang penyuluh dan mendampingi penyuluh 
PNS dalam hal melakukan koordinasi dan konsultasi dengan penyuluh PNS dan kelembagaan penyuluhan diwilayahnya, selain itu bantuan biaya di BKP5K Kabupaten Bogor akan diberikan apabila PPS membuat laporan kegiatan penyuluhan. Dukungan pemerintah daerah setempat dalam memberikan reward kepada PPS sangat diperlukan berupa insentif atau honorarium.

Hubungan antara penghargaan dengan kewajiban PPS dari hasil analisis ini menunjukan bahwa penghargaan berkorelasi positif atau berhubungan signifikan dengan kewajiban PPS yaitu melakukan koordinasi dan konsultasi dengan Penyuluh Perikanan PNS dan kelembagaan penyuluhan perikanan diwilayahnya, dan berkorelasi positif atau berhubungan signifikan dengan kewajiban PPS yaitu membuat laporan. Dengan demikian hasil dari penelitian tentang hubungan ini menyatakan bahwa penghargaan berpengaruh langsung terhadap kewajiban PPS yakni melakukan koordinasi dan konsultasi dengan Penyuluh Perikanan PNS dan kelembagaan penyuluhan perikanan diwilayahnya, dan membuat laporan kegiatan bulanan.

Hubungan antara keikutsertaan dalam kegiatan dengan kewajiban PPS dari hasil analisis ini menunjukkan bahwa keikutsertaan dalam kegiatan berkorelasi positif atau berhubungan signifikan dengan kewajiban PPS yaitu melakukan koordinasi dan konsultasi dengan Penyuluh Perikanan PNS dan kelembagaan penyuluhan perikanan diwilayahnya, berkorelasi positif atau berhubungan signifikan dengan kewajiban PPS yaitu kemitraan dengan Penyuluh Perikanan PNS, dan juga berkorelasi positif atau berhubungan signifikan dengan kewajiban PPS yaitu membuat laporan. Dengan demikian hasil dari penelitian tentang hubungan ini menyatakan bahwa keikutsertaan dalam kegiatan berpengaruh langsung terhadap kewajiban PPS yakni melakukan koordinasi dan konsultasi dengan Penyuluh Perikanan PNS dan kelembagaan penyuluhan perikanan diwilayahnya, kemitraan dengan Penyuluh Perikanan PNS dan membuat laporan kegiatan bulanan.

\section{KESIMPULAN DAN SARAN}

\section{Kesimpulan}

Berdasarkan hasil analisis uji Pearson Chi Square dengan taraf kepercayaan $\sigma=0.05$ menunjukkan bahwa karakteristik internal/pribadi PPS yang berhubungan dengan kewajiban PPS adalah sebagai berikut : 
a. Umur berhubungan nyata dengan kemitraan antara PPS dengan Penyuluh Perikanan PNS.

b. Pendidikan berhubungan nyata dengan pelatihan bidang penyuluhan perikanan.

c. Kekosmopolitanan berhubungan nyata dengan intensitas melakukan kegiatan penyuluhan perikanan, dan koordinasi dan konsultasi dengan Penyuluh Perikanan PNS dan kelembagaan penyuluhan perikanan diwlayahnya serta dengan membuat laporan kegiatan bulanan.

d. Pengalaman usaha berhubungan nyata dengan intensitas melakukan kegiatan penyuluhan perikanan, dengan bekerja atas dasar sukarela dan tidak menerima gaji/honorarium sebagaimana Penyuluh Perikanan PNS, dan dengan kemitraan dengan Penyuluh Perikanan PNS serta membuat laporan laporan bulanan.

e. Motivasi menjadi PPS berhubungan nyata dengan intensitas melakukan kegiatan penyuluhan perikanan dan dengan mengikuti pelatihan bidang penyuluhan perikanan, serta dengan bekerja atas dasar sukarela dan tidak menerima gaji sebagaimana Penyuluh Perikanan PNS.

Hasil analisis uji Pearson Chi Square dengan taraf kepercayaan $\sigma=0.05$ menunjukkan bahwa karakteristik eksternal/hak PPS yang berhubungan dengan kewajiban PPS adalah sebagai berikut :

a. Pengakuan resmi dari pemerintah berhubungan nyata dengan intensitas melakukan kegiatan penyuluhan perikanan, dan dengan melakukan koordinasi dan konsultasi dengan Penyuluh Perikanan PNS dan kelembagaan penyuluhan perikanan di wilayahnya.

b. Sarana dan prasarana berhubungan nyata dengan bekerja atas dasar sukarela dan tidak menerima gaji/honorarium sebagaimana Penyuluh Perikanan PNS.

c. Bantuan biaya berhubungan nyata dengan melakukan koordinasi dan konsultasi dengan Penyuluh Perikanan PNS dan kelembagaan penyuluhan perikanan diwilayahnya, dan kemitraan dengan Penyuluh Perikanan PNS, serta membuat laporan kegiatan bulanan.

d. Penghargaan berhubungan nyata dengan melakukan koordinasi dan konsultasi dengan Penyuluh Perikanan PNS dan kelembagaan penyuluhan perikanan diwilayahnya dan membuat laporan kegiatan bulanan.

e. Keikutsertaan dalam kegiatan yang difasilitasi oleh pemerintah 
berhubungan nyata dengan melakukan koordinasi dan konsultasi dengan Penyuluh Perikanan PNS dan kelembagaan penyuluhan perikanan diwilayahnya, dan kemitraan dengan Penyuluh Perikanan, serta membuat laporan kegiatan bulanan.

\section{Saran}

1. Dengan memperhatikan hal-hal tersebut diatas PPS memiliki potensi untuk menjadi alternatif penggerak kegiatan perikanan diwilayahnya, berdampingan dengan aktivitas yang dilakukan oleh Penyuluh Perikanan PNS, untuk itu diperlukan upayaupaya untuk terus memberikan motivasi dan dukungan kepada PPS agar dapat konsisten dan kontinu melakukan kegiatan penyuluhan perikanan bagi masyarakat pembudidaya/pengolah disekitarnya.

2. Perlu adanya upaya dari lembaga penyuluhan untuk dapat meningkatkan aktivitas PPS dengan melengkapi fasilitas sarana dan prasarana dalam kegiatan penyuluhan perikanan, dan peningkatan pengetahuan dan keterampilan bidang ilmu penyuluhan dalam rangka peningkatan kompetensi PPS dalam melaksanakan kegiatan penyuluhan perikanan.

3. Untuk lebih lanjut melihat kinerja PPS, dinilai perlu untuk mengkaji lebih lanjut aspek capaian tingkat kinerja PPS ini, dengan memperhatikan aspek-aspek yang secara langsung maupun tidak langsung mengenai kinerja PPS tersebut.

\section{DAFTAR PUSTAKA}

Hamzah I, 2011. Tingkat kapasitas Pembudidaya Ikan dalam Mengelola Usaha Akuakultur secara Berkelanjutan . Jurnal Penyuluhan . Bogor. IPB

Keputusan Kepala Badan Sumber daya Manusia Kelautan dan Perikanan No. 76 Tahun 2011 Tentang Pembinaan Penyuluh Perikanan Swadaya

Mardikanto. T. 2009. Sistem Penyuluhan Pertanian. Universitas Sebelas Maret. Surakarta

Mulyasa. 2002. Kurikulum Berbasis Kompetensi. Konsep, Karakteristik, dan Implementasi. Bandung: Remaja Rosdakarya.

Programa Penyuluhan Perikanan Kabupaten Bogor Tahun 2013. Badan Ketahanan Pangan dan Pelaksana Penyuluhan Pertanian, Perikanan dan Kehutanan. Bogor

Pusat Penyuluhan Kelautan dan Perikanan. 2013. Data Penyuluh Perikanan. Simluh KP 
Rogers. Carl L 1969. Freedom to Learn. Charles E. Merill Publishing Company. Columbus. Ohio

Suryantini, H. 2003. Kebutuhan Informasi dan Motivasi Kognitif Penyuluh Pertanian serta Hubungannya dengan Penggunaan Sumber Informasi, Kabupaten Bogor. Jurnal Perpustakaan Pertanian, IPB. Bogor.

Sapar. 2011. Faktor-faktor yang Mempengaruhi Kinerja Penyuluh Pertanian dan Dampaknya pada Kompetensi Petani Kakao di Empat Wilayah Sulawesi Selatan. Disertasi. Bogor

Sumardjo. 2010. Penyuluhan Мепијu Pengembangan Kapital Manusia dan Kapital Sosial Dalam Mewujudkan Kesejahteraan Rakyat. Orasi Ilmiah Guru Besar Dalam Rangka Dies Natalis IPB ke-47. Bogor: Institut Pertanian Bogor.

Undang-Undang No. 16 Tahun 2006 tetang Sistem Penyuluhan Pertanian, Perikanan dan Kehutanan

Van den Ben, AW dan Hawkins, HS. 1999. Penyuluhan Perikanan. Yogyakarta.

Penerbit Kanisius. 